Discussion Paper No. 647

THE BYRD AMENDMENT AS FACILITATING A TACIT INTERNATIONAL BUSINESS COLLUSION

\author{
Yoshitomo Ogawa \\ and \\ Yoshiyasu Ono
}

January 2006

The Institute of Social and Economic Research

Osaka University

6-1 Mihogaoka, Ibaraki, Osaka 567-0047, Japan 


\title{
The Byrd Amendment as Facilitating a Tacit International Business Collusion*
}

\author{
by \\ Yoshitomo Ogawa ${ }^{\dagger}$ and Yoshiyasu Ono
}

\begin{abstract}
We analyze the effect of the Byrd Amendment, which amended the US Tariff Act of 1930 to allow revenue from antidumping duties to be distributed to domestic import-competing firms. In an international duopoly framework it is shown that it urges the home firm to restrict output so that the foreign firm increases output and that revenue from the duties increases. Consequently, not only the home firm but also the foreign firm can be better off while only consumers are worse off. Home total surplus increases if the foreign rival firm is much more efficient, but otherwise decreases.
\end{abstract}

JEL classification: F12, F13.

Keywords: Byrd Amendment, Continued Dumping and Subsidy Offset Act (CDSOA), Antidumping duty, Tariff-revenue distribution.

* This research is financially supported by the $21^{\text {st }}$ Century COE Program of the Ministry of Education, Culture, Sports, Science, and Technology.

$\dagger$ Department of Economics, Kinki University, 3-4-1, Kowakae, Higashi-Osaka City, Osaka 577-8502, JAPAN; E-mail: ogawa@eco.kindai.ac.jp

\$ Institute of Social and Economic Research, Osaka University, 6-1, Mihogaoka, Ibaraki, Osaka 567-0047, JAPAN; E-mail: ono@iser.osaka-u.ac.jp 


\section{Introduction}

In October 2000, the US Congress amended the Tariff Act of 1930 to allow revenue from antidumping and countervailing duties to be distributed to US firms that petition or support the application of those duties. This is the so-called Byrd Amendment, ${ }^{1}$ which is officially known as the Continued Dumping and Subsidy Offset Act (the CDSOA). US firms eligible for distribution are not only protected by antidumping duties but also receive offset payments, thus receiving double protection. ${ }^{2}$

Foreign firms that export to the US and their home countries criticize the US CDSOA as being contrary to the Antidumping Agreements of the World Trade Organization (WTO). Many economists, such as Bhagwati and Mavroidis (2004), support this argument. ${ }^{3}$ In July 2001, Australia, Brazil, Chile, the European Community (EU), India, Indonesia, Japan, Korea, and Thailand called for the WTO to investigate the CDSOA. In September 2001, the panel judged the CDSOA to be inconsistent with US obligations under the WTO Antidumping Agreements and directed the US to withdraw it. Although the US appealed to the WTO, in January 2003, the appellate body concluded that the CDSOA was inconsistent with WTO rules. However, the US Congress has not yet repealed the Byrd Amendment, and many US companies, particularly those in the bearing and steel industries, have received offset payments. $^{4}$ In the fiscal year 2003 , US $\$ 280$ million was distributed among 2,100 claimants. ${ }^{5}$ The EU and Canada in May 2005 and Japan in September 2005 put tariffs on particular goods to counter the CDSOA. ${ }^{6}$ Eventually, the bill that repeals the Byrd Amendment passed the US Congress in December 2005 and January 2006. However, the amendment is valid until October 2007 and thus is still posing a problem for the international economy.

Studies of the antidumping duty include those of Dixit (1988), Anderson (1992), Prusa (1992), Staiger and Wolak (1992), Reitzes (1993), Anderson, Schmitt and Thisse (1995),

\footnotetext{
Act.

${ }^{1}$ The Byrd Amendment is named for Senator Robert Byrd of West Virginia, who introduced the amending

${ }^{2}$ A similar policy is being employed in the beef industry of Japan. Tariff revenues from beef imports are distributed among domestic livestock breeders.

${ }^{3}$ Bhagwati and Mavroidis (2004) state that the Byrd Amendment unambiguously provides excessive protection to US producers because the antidumping duty level in the US is the same as the dumping margin.

${ }^{4}$ See Grimmett and Jones (2005) for details of companies that received the offset payments.

${ }^{5}$ See WTO (2004, p. 48) for detail.

${ }^{6}$ In October 2004 the WTO approved the countermeasures against the US CSDOA.
} 
Rosendorff (1996), Blonigen and Park (2002, 2004), and Konings and Vandenbussche (2005). However, the CDSOA is not treated in these studies. In spite of its growing importance to the world economy, surprisingly few studies address this issue; exceptions are Collie and Vandenbussche (2004) and Schmitz and Seale (2004). Instead of explicitly modeling the tax-revenue transfer to home firms under the CDSOA they simply regard it as a change in the welfare weight attached to the tax revenue, that to home firms' profits or that to consumers' surplus. Moreover, they assume the antidumping duty to have a specific form. In this setting the CDSOA does not directly affect any firm behavior. It does so only if the government changes the tariff rate following the change in the welfare weight under the CDSOA.

When analyzing the CDSOA, however, it would be more suitable to model a tariff-revenue transfer to home firms explicitly. Furthermore, a specific tariff may be unsuitable for the present analysis if Cournot oligopoly is considered since any firm behavior is then unaffected. A home firm takes foreign firms' supply as given and thus considers revenue from a specific tariff to be intact from its own behavior. ${ }^{7}$ A foreign firm's behavior is also independent of the transfer. It should also be noted that in reality an antidumping duty is mostly of not a specific, but an ad valorem, form.

Not only to avoid the abovementioned problem but also to consider more plausible policy options, we consider a Cournot duopoly model with an ad valorem tariff and regard the CDSOA policy as a change in the rate of tariff-revenue distribution to the home firm. In this framework the CDSOA directly affects the home firm's behavior and the Cournot equilibrium even if the tariff rate does not change. We examine the effect of the CDSOA on the output and profit of the home firm, those of the foreign exporting firm, and home total surplus under the following two scenarios. One is the case where the tariff rate is predetermined and the other is that where the tariff rate is optimally adjusted to a change in the distribution rate.

We shall find that the CDSOA works as if it facilitates a tacit collusion between the home and the foreign firm at the cost of consumers' surplus especially when the tariff rate is predetermined. Under the CDSOA the home firm restricts output so that the foreign firm increases production and pays higher tariffs. Eventually total supply decreases and thus consumers are worse off while the home firm and the foreign firm always enjoy greater profits. Home total surplus may increase or decrease depending on the market size and the two firms' marginal costs. It indeed increases if the CDSOA is applied to supporting a very inefficient

\footnotetext{
${ }^{7}$ We shall more clearly show this property in footnote 9.
} 
home firm. Even if the tariff rate is optimally chosen following the CDSOA, essentially the same property holds especially when the home firm faces strong foreign penetration.

After presenting the model in section 2, we first treat the case where the tariff rate is predetermined in section 3 . In section 4 we extend the analysis to the case where the tariff rate is also optimally chosen following the distribution rate. Section 5 concludes this paper.

\section{The Model}

We consider a Cournot duopoly model in which a home and a foreign firm supply a homogeneous commodity in the home market. The home government imposes ad valorem tariff $r$ on the supply of the foreign firm and distributes a part of the tariff revenue, whose ratio is $\theta$, to the home firm. ${ }^{8}$ When the import price is $p^{*}$, the domestic price is $p\left(=(1+r) p^{*}\right)$ and the foreign firm's supply is $y$, the total tariff revenue is

$$
r p^{*} y=\gamma p y \quad \text { where } \gamma=r /(1+r)
$$

From the tariff revenue the government transfers $\theta \gamma p y$ to the home firm and receives only $(1-$ $\theta$ ) $\gamma$ py. Since tariff $r$ satisfies $0<r$ and the transfer is non-negative and does not exceed the total tariff revenue,

$$
0<\gamma<1, \quad 0 \leq \theta \leq 1
$$

In this setup the profit of the home firm $\pi$ and that of the foreign firm $\pi^{*}$ are respectively

$$
\begin{gathered}
\pi=f(D) x+\theta \gamma f(D) y-c(x), \\
\pi^{*}=(1-\gamma) f(D) y-c^{*}(y), \\
D=x+y
\end{gathered}
$$

where $x$ is the home firm's output, and $c(x)$ and $c^{*}(y)$ are respectively the cost functions of the home and the foreign firm that satisfy

$$
c^{\prime}>0, \quad c^{\prime \prime} \geq 0, \quad c^{* \prime}>0, \quad c^{* \prime \prime} \geq 0 .
$$

$D$ is home demand and $f(D)$ is the inverse demand function that satisfies

\footnotetext{
${ }^{8}$ An antidumping duty is aimed to offset, partly or completely, the difference between the domestic price in the exporting country and the export price. Since the domestic price in the exporting country is exogenous in the present setting, an advalorem tariff and an antidumping duty have a simply positive relationship. Thus, we can replace the latter by the former in the present analysis.
} 
Assumption 1. $f^{\prime}<0$ and $f^{\prime \prime} m+f^{\prime}<0$ for any $m \in(0, D)$.

The first property implies the demand curve to be negatively sloped and the second one represents the normal case presented by Seade (1980). From (2), the optimal levels of $x$ and $y$ satisfy

$$
\begin{gathered}
\pi_{x}=(x+\theta \gamma y) f^{\prime}+f-c^{\prime}=0, \\
\pi_{y}^{*}=(1-\gamma)\left(f^{\prime} y+f\right)-c^{* \prime}=0,
\end{gathered}
$$

where $\pi_{x}=\partial \pi / \partial x$ and $\pi^{*}{ }_{y}=\partial \pi^{*} / \partial y$. Obviously a change in $\theta$ varies the equilibrium values of $x$ and $y{ }^{9}$

Finally, home total surplus is the sum of the home firm's profit presented in (2), the tariff revenue left for the government, which equals $(1-\theta) \gamma f y$, and consumers' surplus CS. It is given by

$$
W=f(D) x-c(x)+\gamma f(D) y+\mathrm{CS}
$$

where CS satisfies

$$
\mathrm{dCS}=-D f^{\prime} \mathrm{d} D
$$

\section{The CDSOA under a Predetermined Tariff Rate}

First, we assume tariff rate $\gamma$ to be predetermined by the home government. Given $\gamma$, total differentiation of (3) and (4) yields

$$
\begin{gathered}
\pi_{x x} \mathrm{~d} x+\pi_{x y} \mathrm{~d} y=-\gamma f^{\prime} y \mathrm{~d} \theta, \\
\pi^{*}{ }_{y x} \mathrm{~d} x+\pi^{*}{ }_{y y} \mathrm{~d} y=0,
\end{gathered}
$$

where $\pi_{x x}=\partial^{2} \pi / \partial x^{2}, \pi_{x y}=\partial^{2} \pi / \partial x \partial y, \pi^{*}{ }_{y x}=\partial^{2} \pi^{*} / \partial y \partial x$ and $\pi^{*}{ }_{y y}=\partial^{2} \pi^{*} / \partial y^{2}$. From these two equations we obtain

\footnotetext{
${ }^{9}$ If specific tariff $t$ is imposed instead, $\pi=f(x+y) x+\theta t y-c(x)$ and $\pi^{*}=[f(D)-t] y-c^{*}(y)$. Since $\theta t y$ works as a lump-sum transfer to the home firm in this setting, the home firm determines $x$ so that $\partial \pi / \partial x=f(x+y)+f^{\prime}(x+$ $y) x-c^{\prime}(x)=0$, which does not depend on $\theta$. Since the optimal level of $y$ is also independent of $\theta$, the Cournot solution is unaffected by $\theta$, as mentioned in the introduction.
} 


$$
\begin{gathered}
\mathrm{d} x / \mathrm{d} \theta=-\gamma f^{\prime} y \pi^{*}{ }_{y y} / \Pi, \\
\mathrm{d} y / \mathrm{d} \theta=\gamma f^{\prime} y \pi^{*}{ }_{y x} / \Pi,
\end{gathered}
$$

where $\Pi=\pi_{x x} \pi^{*}{ }_{y y}-\pi_{x y} \pi^{*}{ }_{y x}$.

From assumption 1 and (4), $\pi^{*}{ }_{y x}$ satisfies

$$
\pi^{*}{ }_{y x}=(1-\gamma)\left(f^{\prime \prime} y+f^{\prime}\right)<0 .
$$

For the concavity of the profit functions and the stability of the present duopoly we assume

Assumption 2. $\pi_{x x}<0, \pi^{*} y y<0, \Pi>0$.

From (7)-(9) and assumptions 1 and 2, we find

$$
\mathrm{d} x / \mathrm{d} \theta<0, \quad \mathrm{~d} y / \mathrm{d} \theta>0
$$

i.e., an increase in distribution rate $\theta$ reduces the home firm's output and increases the foreign firm's output.

Turning to the effect of distribution rate $\theta$ on the two firms' profits, differentiation of (2), (4) and (10) give

$$
\mathrm{d} \pi^{*} / \mathrm{d} \theta=(1-\gamma) f^{\prime} y(\mathrm{~d} x / \mathrm{d} \theta)>0,
$$

i.e., an increase in the distribution rate raises the foreign firm's profit. It further implies that the foreign firm's profit becomes largest when all the tariff revenue is distributed to the home firm. From (2), (3) and (8) we obtain

$$
\begin{aligned}
& \mathrm{d} \pi / \mathrm{d} \theta=\left[(1-\gamma) \gamma y f^{\prime} / \Pi\right]\left[\left(f^{\prime}+y f^{\prime \prime}\right) c^{\prime}+\left\{2 f^{\prime}+(x+\theta \gamma y) f^{\prime \prime}\right\} f\right] \\
& \quad+[\gamma y f / \Pi]\left[c^{\prime \prime} c^{* \prime \prime}-c^{\prime \prime}(1-\gamma)\left(2 f^{\prime}+y f^{\prime \prime}\right)-c^{* \prime \prime}\left\{2 f^{\prime}+(x+\theta \gamma y) f^{\prime \prime}\right\}\right] .
\end{aligned}
$$

Under assumptions 1 and 2, (12) satisfies

$$
\mathrm{d} \pi / \mathrm{d} \theta>0
$$

i.e., an increase in $\theta$ raises the home firm's profit. The home firm's profit is also maximized when all the tariff revenue is distributed to it.

Finally, from the partial derivative of (4) with respect to $y,(7),(8)$ and (9) we obtain

$$
\mathrm{d} D / \mathrm{d} \theta(=\mathrm{d} x / \mathrm{d} \theta+\mathrm{d} y / \mathrm{d} \theta)=\gamma f^{\prime} y\left[-(1-\gamma) f^{\prime}+c^{* \prime \prime}\right] / \Pi<0 .
$$


From (6) and (14) it is evident that an increase in $\theta$ reduces consumers' surplus CS and that CS is minimized when all the tariff revenue is distributed to the home firm.

We summarize the properties given by (10), (11), (13) and (14) as follows:

Proposition 1. If the government raises the ratio of tariff revenue distributed to the home firm under the CDSOA, the home firm decreases, and the foreign firm increases, output. Consequently, both firms receive higher profits whereas consumers' surplus decreases. Furthermore, distributing all the tariff revenue to the home firm is most desirable for both firms and most harmful for consumers.

As the distribution rate increases, the home firm behaves so that the tariff revenue increases. In doing so it reduces output so that the foreign firm expands supply and the price rises, both of which increase the tariff revenue. Consequently, not only the home firm but also the foreign firm enjoys a larger profit. Only the consumers of this commodity suffer a welfare loss from the price rise. ${ }^{10}$ Thus, the CDSOA facilitates a tacit collusion between home and foreign firms that enables them to raise price and enjoy higher profits at the cost of consumers' surplus. Note that an antidumping duty alone works on the two firms' outputs oppositely to the CDSOA -i.e., the foreign firm reduces output and the home firm supplies more. ${ }^{11}$

A similar tacit collusion also arises under a voluntary export restraint (VER). ${ }^{12}$ However, it makes the foreign firm restrict export and thereby brings higher profits to both firms. In contrast, the CDSOA urges the foreign firm to produce more and pay more tariffs, benefiting both firms.

Let us next investigate the effect of a change in the distribution rate on home total surplus $W$ given by (5). From (2) - (6), $\mathrm{d} W / \mathrm{d} \theta$ is

$$
\mathrm{d} W / \mathrm{d} \theta=[-D+(1-\theta) \gamma y] f^{\prime} \mathrm{d} x / \mathrm{d} \theta+\left[\gamma f-(1-\gamma) y f^{\prime}\right] \mathrm{d} y / \mathrm{d} \theta
$$

\footnotetext{
${ }^{10}$ Obviously consumers' surplus CS indicates the benefit of the households that consume the present commodity. The tariff revenue left for the government $(1-\theta) \gamma p y$ and the home firm's profit $\pi$ are distributed among all households, whether they consume the commodity or not, in the home country as transfers and dividends respectively. Total surplus $W$ is given by the sum of all of them.

${ }^{11}$ See, for example, Dixit (1988) and Bhagwati, Panagariya and Srinivasan (1998, p. 403) for this property of an antidumping duty or an import tariff.

${ }^{12}$ Such a mechnism of a quantitative trade restriction is first modelled by Itoh and Ono (1982), Ono (1984) and Krishna (1989). Rosendorf (1996) shows that a foreign firm imposes a VER leading to such a tacit collusion in order to avoid the importing country to levy an antidumping duty.
} 
where $\mathrm{d} x / \mathrm{d} \theta$ and $\mathrm{d} y / \mathrm{d} \theta$ are given by (7) and (8). In order to make the welfare effect tractable, we assume a linear demand function and constant marginal costs of the two firms:

$$
f(D)=\beta-\alpha D, c^{\prime}(x)=c=\text { constant }, c^{* \prime}(y)=c^{*}=\text { constant } .
$$

Under (16) optimal conditions (3) and (4) give the equilibrium values of $x$ and $y$ :

$$
\begin{gathered}
x=\left[(1-\theta \gamma) \beta-2 c+(1+\theta \gamma) c^{* /(}(1-\gamma)\right] /[\alpha(3-\theta \gamma)], \\
y=\left[\beta+c-2 c^{*} /(1-\gamma)\right] /[\alpha(3-\theta \gamma)] .
\end{gathered}
$$

Substituting these values and (16) into (15) yields

$$
\begin{gathered}
A \mathrm{~d} W / \mathrm{d} \theta=-(3-2 \gamma)\left(\beta / c^{*}\right)+[3+2 \gamma(1-\theta)]\left(c / c^{*}\right)+\gamma[\theta-(1-\theta) /(1-\gamma)], \\
\text { where } A=\alpha(3-\theta \gamma)^{2} /\left(\gamma y c^{*}\right)>0 .
\end{gathered}
$$

By equalizing (18) to zero we obtain the optimal $\theta$ as a function of $\beta / c^{*}$ and $c / c^{*}$ :

$$
\theta=\theta^{\mathrm{opt}}\left(\beta / c^{*}, c / c^{*}\right)
$$

In order for this value to be indeed optimal, total surplus function $W$ must be concave with respect to $\theta$ and thus

$$
\mathrm{d}^{2} W / \mathrm{d} \theta^{2}=(2 \gamma / A)\left(1+\frac{\gamma}{2(1-\gamma)}-c / c^{*}\right)<0
$$

From (18) and (19) $\theta^{\text {opt }}$ satisfies

$$
\begin{gathered}
\partial \theta^{\mathrm{opt}} / \partial \beta=(3-2 \gamma) /\left[A c^{*} \mathrm{~d}^{2} W / \mathrm{d} \theta^{2}\right]<0, \\
\partial \theta^{\mathrm{opt}} / \partial c=-[3+2 \gamma(1-\theta)] /\left[A c^{*} \mathrm{~d}^{2} W / \mathrm{d} \theta^{2}\right]>0, \\
\partial \theta^{\mathrm{opt}} / \partial c^{*}=-\gamma[\theta-(1-\theta) /(1-\gamma)] /\left[A c^{*} \mathrm{~d}^{2} W / \mathrm{d} \theta^{2}\right] .
\end{gathered}
$$

Note that $\partial \theta^{\mathrm{opt}} / \partial c^{*}$ can be either positive or negative. It is because a rise in $c^{*}$ works as if it lowers $\beta$ and $c$ at the same time, as seen from (18), generating positive and negative effects on $\theta^{\text {opt }}$. These results are summarized as follows.

Proposition 2. The larger the market size is or the lower the marginal cost of the home firm is, the lower the optimal distribution rate is. A rise in the foreign firm's marginal cost can either raise or lower the optimal distribution rate. 
As stated in proposition 1, the CDSOA urges the home firm to reduce output and give a larger market share to the foreign firm so that the tariff revenue from the foreign firm increases. In this process the total output decreases and thus consumer's surplus declines. Having this property in mind, let us discuss the mechanism behind proposition 2. As market size $\beta$ is larger, the loss of consumers' surplus generated by the CDSOA increases, causing the optimal distribution rate to decrease. As the home firm's marginal cost $c$ increases, the difference between the price and the marginal cost declines, implying that the cost of a reduction in the home firm's output due to the CDSOA decreases. Thus, the optimal distribution rate increases.

The effect of a rise in $c^{*}$ on the optimal distribution rate is twofold. It lowers the effect of a reduction in the home firm's output on an expansion in the foreign firm's output. Thus, the beneficial effect of the tariff-revenue distribution decreases. However, it raises the equilibrium price, causing the tariff revenue per foreign output to increase. Thus, the benefit of expanding the foreign firm's output owing to the tariff-revenue distribution increases. Because of these two opposite effects we obtain the mixed result.

Note that the optimal distribution rate can even be zero (no distribution to the home firm) or 1 (full distribution to the home firm). In fact, from (18) we find

$$
\begin{gathered}
A \mathrm{~d} W /\left.\mathrm{d} \theta\right|_{\theta=0}=-(3-2 \gamma)\left(\beta / c^{*}\right)+(3+2 \gamma)\left(c / c^{*}\right)-\gamma /(1-\gamma), \\
A \mathrm{~d} W /\left.\mathrm{d} \theta\right|_{\theta=1}=-(3-2 \gamma)\left(\beta / c^{*}\right)+3\left(c / c^{*}\right)+\gamma .
\end{gathered}
$$

If market size $\beta$ is large enough in comparison to $c$, the value of the first equation is negative. ${ }^{13}$ Thus, in this case $\theta^{\text {opt }}$ is 0 , implying that no distribution of the tariff revenue to the home firm is optimal. If market size $\beta$ is small enough, the second equation of (20) is positive, implying that $\theta^{\text {opt }}$ is $1 .{ }^{14}$ Thus, full distribution of the tariff revenue to the home firm is optimal. Furthermore, if $\beta$ is so small or $c$ is so large that the home firm's supply given by (17) is negative when $\theta=1$, the government should set a high enough distribution rate for the home firm to stop producing the commodity. ${ }^{15}$

\footnotetext{
${ }^{13}$ In this case $x$ and $y$ given by (17) are positive, and thus the policy with $\theta=0$ is feasible.

${ }^{14}$ If $\beta$ is too small or if $c$ is too large, $x$ given in (17) becomes negative. In order for $x$ and the second equation of (20) to be both positive, $c$ must satisfy $\left[(1-\gamma)\left(\beta / c^{*}\right)+(1+\gamma) /(1-\gamma)\right] / 2>c / c^{*}>(1-2 \gamma / 3)\left(\beta / c^{*}\right)-\gamma / 3$. This range exists if $\beta / c^{*}<(1+2 \gamma) /(1-\gamma)$. All these conditions are satisfied if e.g. $\gamma=0.3, \beta / c^{*}=2$ and $c / c^{*}=1.6$.

${ }^{15}$ Under the US CDSOA, however, a firm is not entitled to receive tariff-revenue payments unless it actually produces the commodity. Thus, the optimal distribution rate is such that the home firm produces the minimal amount required to be identified as a firm in production.
} 


\section{Tariff-rate Adjustment and the CDSOA}

Whereas the tariff rate is assumed to be predetermined in section 3 , in this section the government is assumed to adjust the tariff rate optimally when changing the distribution rate. In this setup we examine the effect of an increase in the distribution rate on home total surplus and the profits of the home and foreign firms.

\section{A. Optimal Tariff under the CDSOA}

First, we examine. Taking $\theta$ as given, total differentiation of (5) with respect to $\gamma$ yields

$$
\mathrm{d} W / \mathrm{d} \gamma=[-D+(1-\theta) \gamma y] f^{\prime} \mathrm{d} x / \mathrm{d} \gamma+\left[\gamma f-(1-\gamma) y f^{\prime}\right] \mathrm{d} y / \mathrm{d} \gamma+y f
$$

From (3) and (4) we derive

$$
\begin{gathered}
\pi_{x x} \mathrm{~d} x+\pi_{x y} \mathrm{~d} y=-\theta y f^{\prime} \mathrm{d} \gamma, \\
\pi^{*}{ }_{y x} \mathrm{~d} x+\pi^{*}{ }_{y y} \mathrm{~d} y=\left(f^{\prime} y+f\right) \mathrm{d} \gamma,
\end{gathered}
$$

from which

$$
\begin{aligned}
\mathrm{d} x / \mathrm{d} \gamma & =\left[-\theta y f^{\prime} \pi_{y y}^{*}+\left(f^{\prime} y+f\right) \pi_{x y}\right] / \Pi, \\
\mathrm{d} y / \mathrm{d} \gamma & =\left[\left(f^{\prime} y+f\right) \pi_{x x}+\theta y f^{\prime} \pi^{*}{ }_{y x}\right] / \Pi,
\end{aligned}
$$

where $\Pi$ is given in (8). They are $\mathrm{d} x / \mathrm{d} \gamma$ and $\mathrm{d} y / \mathrm{d} \gamma$ located in the right-hand side of (21).

Given the complexity of the present analysis, we take a simulation method by assuming the linear demand and the constant marginal costs given by (16). By substituting (16) into (21) and (22) and solving $\gamma$ that makes $\mathrm{d} W / \mathrm{d} \gamma$ equal 0 we obtain the optimal level of $\gamma$ as a function of $\theta, \beta / c^{*}$ and $c / c^{*}$. It is

$$
\gamma=\gamma^{\mathrm{opt}}\left(\theta ; \beta / c^{*}, c / c^{*}\right)
$$

where $\gamma^{\text {opt }}$ is the solution of

$$
\begin{aligned}
{\left[\alpha(3-\theta \gamma)^{3} / c^{* 2}\right] \mathrm{d} W / \mathrm{d} \gamma=(3-3 \theta+\theta \gamma)\left(\beta / c^{*}\right)^{2}+\left(6+2 \theta \gamma-2 \theta^{2} \gamma\right)\left(\beta / c^{*}\right)\left(c / c^{*}\right) } \\
+\left(3+3 \theta+\theta \gamma-2 \theta^{2} \gamma\right)\left(c / c^{*}\right)^{2} \\
+\left(-3+6 \theta-7 \theta \gamma-4 \theta^{2} \gamma^{2}+5 \theta \gamma^{2}+2 \theta^{2} \gamma+\theta^{2} \gamma^{3}\right)\left(\beta / c^{*}\right) /(1-\gamma)^{2} \\
+\left(-12-6 \theta+2 \theta \gamma+5 \theta \gamma^{2}+\theta^{2} \gamma^{3}+6 \theta^{2} \gamma-3 \theta^{2} \gamma^{2}-\theta^{3} \gamma^{3}\right)\left(c / c^{*}\right) /(1-\gamma)^{2}
\end{aligned}
$$




$$
\begin{aligned}
& +\left(3+\theta \gamma-6 \gamma+6 \theta \gamma^{2}+3 \theta^{2} \gamma^{2}-4 \theta^{2} \gamma^{3}-4 \theta^{2} \gamma+\theta^{3} \gamma^{3}\right) /(1-\gamma)^{3} \\
& =0
\end{aligned}
$$

From the numerical analysis on (23), we obtain a positive relationship between $\theta$ and $\gamma^{\text {opt }}$, as shown in figure 1 where $\beta / c^{*}=4$ and $c / c^{*}=2 .{ }^{16}$ Furthermore, we find such a positive relationship for any value of $\beta / c^{*} \in[1.1,20]$ and $c / c^{*} \in[0.5$, min. $(\beta, 10)]$ both with an interval of $0.1 .^{17}$

In conclusion, the optimal tariff rate increases as the rate of tariff revenue distributed to the home firm increases. This property is intuitively explained as follows. The CDSOA policy reduces the home firm's output, increases the foreign firm's output $y$ and raises price $p$, as stated in proposition 1. Consequently, the foreign firm's revenue $p y$, which is the tariff base, increases. It implies the marginal benefit of the tariff to rise and hence the optimal tariff rate to be higher. ${ }^{18}$

\section{B. Welfare Effect of the CDSOA with Tariff-Rate Adjustment}

Next, we examine the effects on the home and foreign firms' profits given by (2) and home total surplus $W$ given by (5) of a change in the distribution rate when the tariff rate is optimally adjusted. Under the linear demand and the constant marginal costs given by (16) the shapes of the three functions in three typical cases are illustrated in figure 2 (see the appendix for the expressions of the three functions). Given that $\beta / c^{*}=15$, they are case (i) in which $c / c^{*}$ $=6.8$, case (ii) in which $c / c^{*}=5.8$, and case (iii) in which $c / c^{*}=1.1$.

As shown in figure 2, if the home firm is much less efficient than the foreign firm (case i), more distribution to the home firm raises not only both firms' profits but also home total surplus. Moreover, home total surplus is maximized when the government distributes the tariff revenue so much that the home firm almost ceases production and only receives the

\footnotetext{
${ }^{16}$ Note that $\gamma^{\text {opt }}$ is independent of $\alpha$.

${ }^{17}$ In this numerical analysis the concavity is found to be valid at every set of $\left(\theta, \gamma^{\text {opt }}\right)$ within this range.

${ }^{18}$ Assuming a specific tariff, Collie and Vandenbussche (2004) find a negative relationship between the CDSOA policy and the optimal tariff. It is because they assume the government to attach a higher weight to the home firm's profit than to the tariff revenue and to consumers' surplus and regard the CDSOA as not the tariff-revenue transfer but raising the weight attached to the tariff revenue. In this setting the tariff rate is set at a higher level than maximizes the tariff revenue so that the home firm obtains a high profit. Since the CDSOA raises the importance of the tariff revenue relative to that of the home firm's profit, the government reduces the tariff rate so as to increase the tariff revenue.
} 
tariff-revenue transfer. ${ }^{19}$ As the home firm's efficiency improves, partial distribution becomes optimal since home total surplus forms a humped shape. It in fact arises when e.g. $c / c^{*}=6.2$, which we do not exhibit in figure 2. A further improvement in the home firm's efficiency makes no distribution optimal for the home country while full distribution still most benefits both firms (case ii). This result is in conformity with that for the case where the tariff rate is predetermined, which is summarized in proposition 2. Finally, if the home firm's cost inferiority to the foreign firm is small (case iii), it harms the foreign firm and the home country while benefiting only the home firm.

Let us intuitively discuss the above result. First, the tariff-revenue distribution to the home firm anyway benefits the home firm. Second, if the home firm is very inefficient, the foreign firm supplies a lot, implying the benefit of raising the tariff rate owing to an increase in the distribution rate to be great. Additionally, since the home firm's profit per output is low, the surplus loss due to its output reduction induced by the CDSOA is small. Thus, the CDSOA benefits the home country. Third, as the home government raises the distribution rate and the corresponding optimal tariff rate, the home firm tries to increase the tariff-revenue transfer by decreasing output. The home firm's output reduction benefits, while the tariff-rate increase harms, the foreign firm. If the home firm is very inefficient, it takes the tariff revenue more significant than its own profits and hence vastly reduces output. It causes the former effect to dominate the latter, making the foreign firm better off. The opposite mechanism works if the cost inferiority of the home firm to the foreign firm is small.

In sum, the CDSOA with optimal tariff-rate adjustment benefits both countries if the home firm is much less efficient than the foreign firm. If the home firm's cost inferiority to the foreign firm is small, however, the CDSOA harms both countries while making only the home firm better off.

\section{Conclusion}

We analyze the implication of the US Continued Dumping and Subsidy Offset Act (CDSOA, otherwise known as the Byrd Amendment) using an international Cournot duopoly model. Under the CDSOA the home government imposes an ad valorem tariff on the foreign

\footnotetext{
${ }^{19}$ It implies that removing a much less efficient firm benefits the world economy. This result is consistent with that of Lahiri and Ono (1988; 2004, Chapters 1 and 4) -i.e., removing a very inefficient firm from the market raises total welfare in a closed economy. Also, note that under the US CDSOA a firm has to keep producing a minimal amount of the commodity in order to receive tariff-revenue payments, as stated in footnote 14 .
} 
firm to protect the home import-competing firm and further distributes a part of the tariff revenue to the home firm, --i.e., the home firm receives double protection. We examine the effects of this policy on the home firm's profit, the foreign firm's profit and home total surplus.

Although foreign firms and governments criticize the US CDSOA, we find that it always benefits the foreign firm as well as the home firm if the tariff rate is predetermined. It urges the home firm to restrict output so that the foreign firm increases production and pays higher tariffs. Thus, the commodity price rises and home consumers are worse off. In sum, the CDSOA facilitates a tacit collusion between the home and the foreign firm at the cost of consumers' surplus. Consequently, home total surplus may increase or decrease depending on the market size and the two firms' marginal costs. Particularly, if the market is sufficiently large or if the home firm's cost inferiority to the foreign firm is small, distributing no tariff revenue to the home firm is the optimal policy. However, if the market size is sufficiently small or if the home firm is much less efficient than the foreign firm, the CDSOA increases home total surplus as well as both firms' profits.

If the tariff rate is optimally chosen, an increase in the distribution rate raises the optimal tariff rate, viz. a result that may be a concern to the foreign firm. Despite an increase in the tariff rate, however, the foreign firm's profit increases under the CDSOA as long as it is much more efficient than the home firm. It does because increases in the distribution rate and the tariff rate make it profitable for the home firm to expand tariff revenue by reducing output significantly and giving a larger market share to the foreign firm. While both firms enjoy the benefit of the CDSOA, only home consumers are worse off. The loss of consumers is however dominated by the increases in the home firm's profit and the tariff revenue.

If the cost superiority of the foreign firm over the home firm is not so outstanding, the loss of consumers is so large that home total surplus declines whereas the foreign firm is still better off. Furthermore, if the foreign firm's superiority over the home firm is small, the CDSOA reduces not only home total surplus but also the foreign firm's profit.

In sum, if the home firm faces a much stronger foreign rival firm, the CDSOA benefits not only the home country but also the foreign firm, although most foreign exporters complain of it. However, if the home firm is not so much inferior to the foreign firm, the government should not apply the CDSOA to the industry since it harms both the foreign firm and the home country while only the home firm is better off. 


\section{Appendix: Functional Forms under Linear Demand and Costs}

Applying (16) and (17) to (2) and (5) yields the following functions:

$$
\begin{aligned}
\left(\frac{\alpha}{c^{* 2}}\right) \pi= & \frac{\left(\frac{\beta}{c^{*}}+\frac{1-\theta \gamma}{1-\gamma}\right)^{2}-\left[(4-\theta \gamma)\left((1-\theta \gamma) \frac{\beta}{c^{*}}-\frac{c}{c^{*}}\right)+\frac{4}{1-\gamma}\right]\left(\frac{c}{c^{*}}\right)}{(3-\theta \gamma)^{2}}, \\
\left(\frac{\alpha}{c^{* 2}}\right) \pi^{*}= & \frac{(1-\gamma)\left(\frac{\beta}{c^{*}}-\frac{c}{c^{*}}+\frac{2}{1-\gamma}\right)^{2}}{(3-\theta \gamma)^{2}}, \\
\left(\frac{\alpha}{c^{* 2}}\right) W= & \frac{\left(3(1-\theta \gamma)+\gamma+\frac{(\theta \gamma)^{2}}{2}\right)\left(\frac{\beta}{c^{*}}\right)^{2}-\left[2(1-\gamma)+(2-\theta \gamma)^{2}\right]\left(\frac{\beta}{c^{*}}\right)\left(\frac{c}{c^{*}}\right)+\left(\frac{9}{2}-2 \theta \gamma+\gamma\right)\left(\frac{c}{c^{*}}\right)^{2}}{(3-\theta \gamma)^{2}} \\
& -\frac{\gamma(1+\theta \gamma-2 \theta)\left(\frac{\beta}{c^{*}}\right)+\left[3+\gamma+\theta \gamma^{2}-(\theta \gamma)^{2}\right]\left(\frac{c}{c^{*}}\right)-\frac{(1-\theta \gamma)(3+\theta \gamma-4 \gamma)}{2(1-\gamma)}}{(1-\gamma)(3-\theta \gamma)^{2}},
\end{aligned}
$$

where $\gamma=\gamma^{\mathrm{opt}}\left(\theta ; \beta / c^{*}, c / c^{*}\right)$ given by (23). Figure 2 illustrates these values as functions of $\theta$. 


\section{References}

Anderson, James E. "Domino Dumping I: Competitive Exporters." American Economic Review, 1992, 82(1), pp. 65-83.

Anderson, Simon P.; Schmitt, Nicolas and Thisse, Jacques-Francois. "Who Benefits from Antidumping Legislation?” Journal of International Economics, 1995, 38(3-4), pp. 321-337.

Bhagwati, Jagdish N. and Mavroidis, Petros. "Killing the Byrd Amendment with the Right Stone." World Trade Review, 2004, 3(1), pp. 119-127.

Bhagwati, Jagdish N.; Panagariya, Arvind and Srinivasan, T. N. Lectures on International Trade, $2^{\text {nd }}$ ed. Cambridge and London: MIT Press, 1998.

Blonigen, Bruce A. and Haynes, Stephen E. "Antidumping Investigations and the Pass-Through of Antidumping Duties and Exchange Rates." American Economic Review, 2002, 92(4), pp. 1044-1061.

Blonigen, Bruce A. and Park, Jee-Hyeong. "Dynamic Pricing in the Presence of Antidumping Policy: Theory and Evidence.” American Economic Review, 2004, 94(1), pp. 135-154.

Collie, David R. and Vandenbussche, Hylke. "Antidumping Duties and the Byrd Amendment." CEPR Discussion Paper 4780, 2004.

Dixit, Avinash. "Antidumping and Countervailing Duties under Oligopoly." European Economic Review, 1988, 32(1), pp. 55-68.

Grimmett, Jeanne J. and Jones, Vivian C. "The Continued Dumping and Subsidy Offset Act (“Byrd Amendment”).” CRS (Congressional Research Service) Report for Congress, 2005, RL33045.

Itoh, Motoshige and Ono, Yoshiyasu. “Tariffs, Quotas and Market Structure." Quarterly Journal of Economics, 1982, 97(2), pp. 295-305.

Konings, Jozef and Vandenbussche, Hylke. "Antidumping Protection and Markups of Domestic Firms.” Journal of International Economics, 2005, 65(1), pp. 151-165.

Krishna, Kala. "Trade Restrictions as Facilitating Practices." Journal of International Economics, 1989, 26(3-4), pp. 251-270.

Lahiri, Sajal and Ono, Yoshiyasu. "Helping Minor Firms Reduces Welfare." Economic Journal, 1988, 98, pp. 1199-1202. 
Lahiri, Sajal and Ono, Yoshiyasu. Trade and Industrial Policy under International Oligopoly, Cambridge University Press, 2004.

Ono, Yoshiyasu. "Profitability of Export Restraint." Journal of International Economics, 1984, 16(3-4), pp. 335-343.

Prusa, Thomas J. "Why Are So Many Antidumping Petitions Withdrawn?" Journal of International Economics, 1992, 33(1-2), pp. 1-20.

Reitzes, James D. “Antidumping Policy.” International Economic Review, 1993, 34(4), 745-763.

Rosendorff, B. Peter. "Voluntary Export Restraints, Antidumping Procedures and Domestic Politics." American Economic Review, 1996, 86(3), pp. 544-561.

Seade, Jesus K. “On the Effects of Entry.” Econometrica, 1980, 48(2), pp. 479-489.

Schmitz, Troy G. and Seale, James L. "Countervailing Duties, Antidumping Tariffs and the Byrd Amendment: A Welfare Analysis.” International Journal of Applied Economics, 2004, 1(1), pp. 65-80.

Staiger, Robert W. and Wolak, Frank A. "The Effect of Domestic Antidumping Law in the Presence of Foreign Monopoly.” Journal of International Economics, 1992, 32(3-4), pp. 265-287.

WTO (World Trade Organization). Trade Policy Review, United States 2004. Geneva: WTO Publications, 2004. 
Figure 1: The optimal tariff rate $\left(\beta / c^{*}=4, c / c^{*}=2\right)$

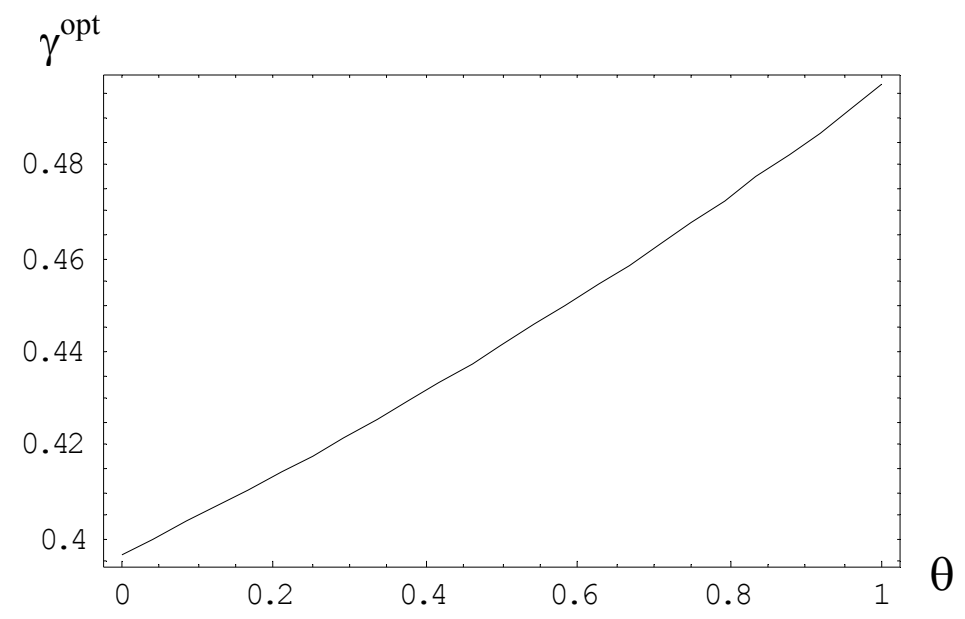


Figure 2: The effect of changing the distribution rate $\left(\beta / c^{*}=15\right)$

(i) $c / c^{*}=6.8,0<\theta<0.60948$ (at which $x=0$ ).

(a) The home firm's profit

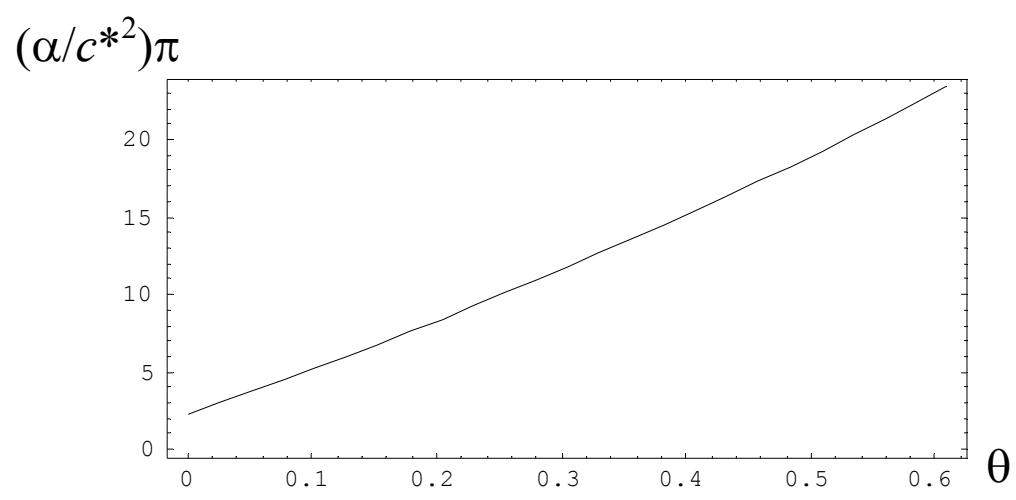

(b) The foreign firm's profit

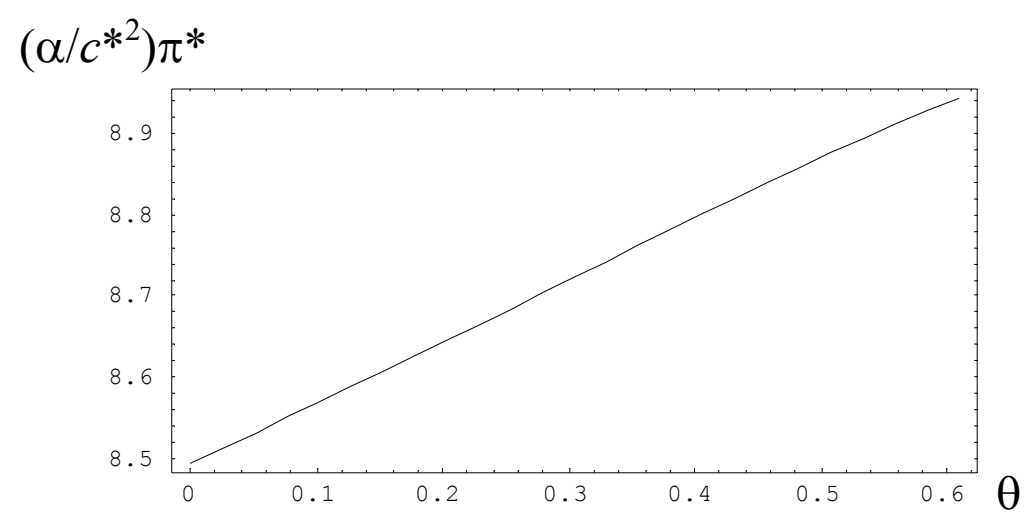

(c) Home total surplus

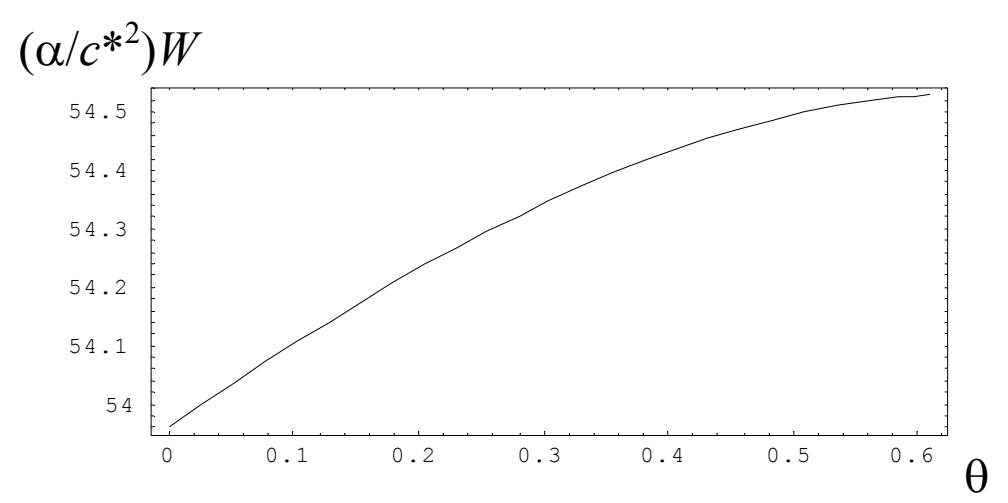


(ii) $c / c^{*}=5.8,0<\theta<0.88365$ (at which $x=0$ ).

(a) The home firm's profit

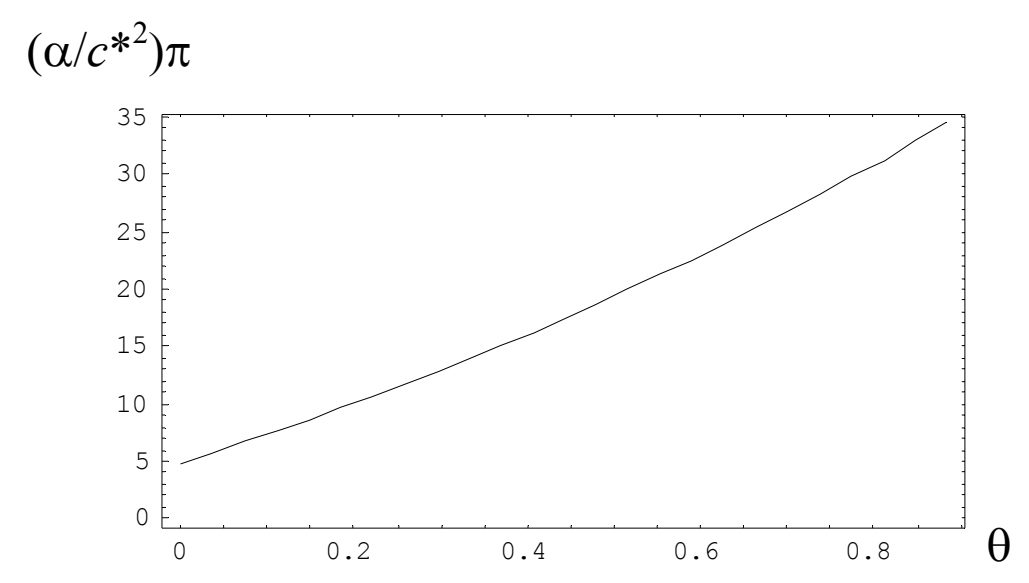

(b) The foreign firm's profit

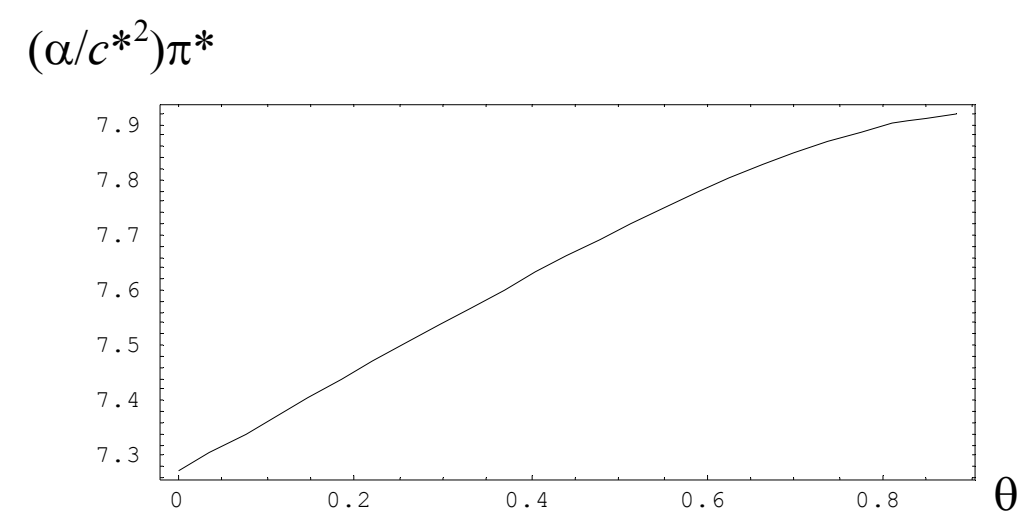

(c) Home total surplus

$\left(\alpha / c^{* 2}\right) W$

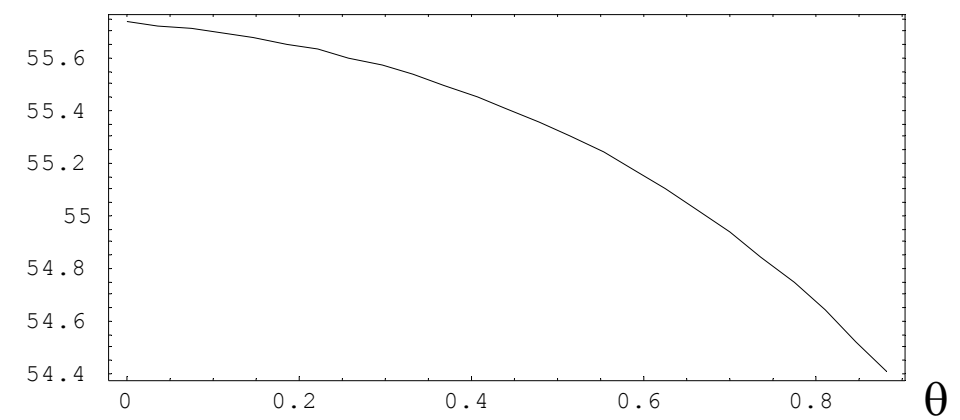


(iii) $c / c^{*}=1.1,0<\theta<1(x>0$ and $y>0$ in this range $)$.

(a) The home firm's profit

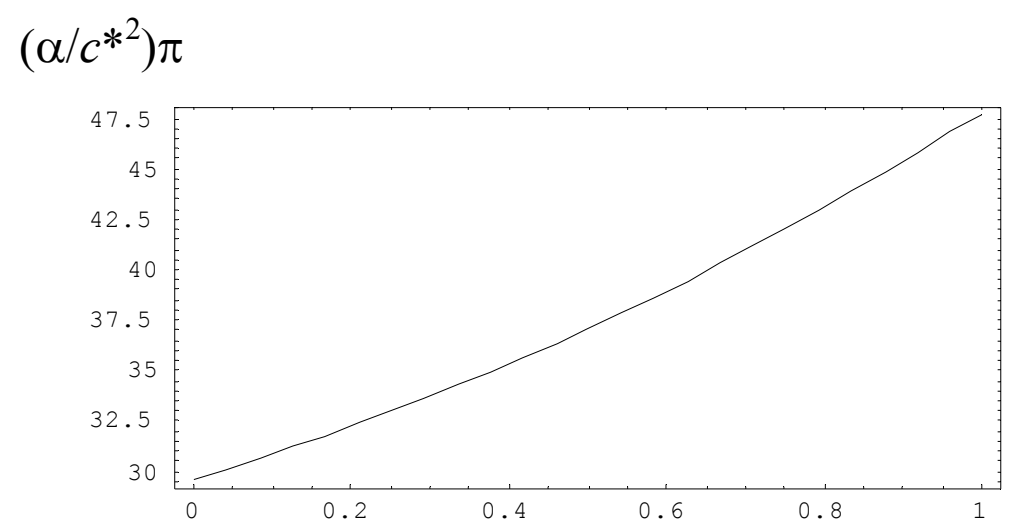

(b) The foreign firm's profit

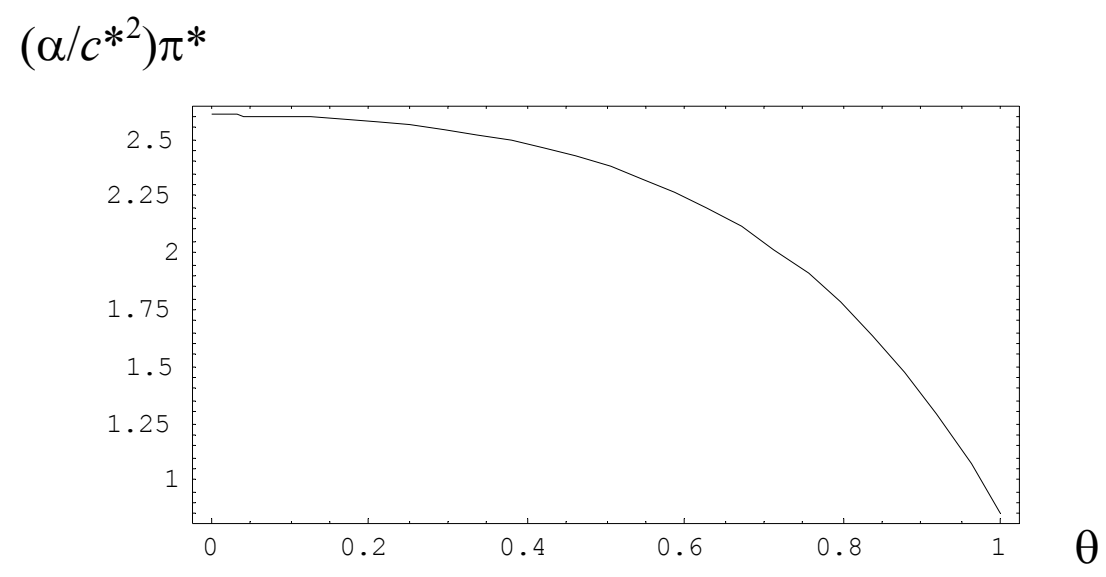

(c) Home total surplus

$\left(\alpha / c^{* 2}\right) W$

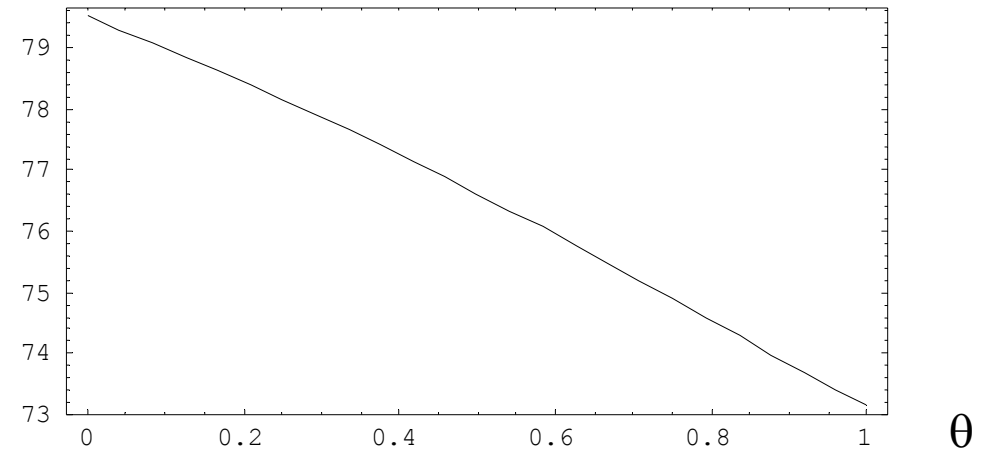

